\title{
FIGHTING FOR POLITICAL FREEDOM: COMPARATIVE STUDIES OF THE LEGAL COMPLEX AND POLITICAL LIBERALISM, TERENCE C. HALLIDAY, LUCIEN KARPIK AND MALCOLM M. FEELEY, EDS. (OXFORD: HART, 2007)
}

Most mainstream media coverage of lawyers tends to focus on individual court rulings or spectacular cases of individual character deficiencies within the legal profession. Consequently, society in general has formed a world view that tends to overlook the role of legal actors in struggling for basic rights in all except the most exceptional cases. Fighting For Political Freedom: Comparative Studies of the Legal Complex and Political Liberalism ${ }^{1}$ thus fills an essential gap in providing a view into worlds where "ordinary" members of the legal complex regularly play pivotal roles in advancing the causes of liberal society. The book frames its arguments by defining a "legal complex" whose core is composed of lawyers and judges, but extends far beyond this to include all legally trained personnel in a society, including civil servants and prosecutors involved in administering justice. The most impressive contribution made by this book is the universality of the theory of the legal complex's relationship to political liberalism, and the application of the theory through a collection of case studies spanning four continents. The 16 case studies in the book provide a particularly useful reference guide for academics and human rights activists in the struggle to establish or protect basic human rights in a wide variety of countries.

Are lawyers "active agents in the construction of liberal political regimes"? ${ }^{2}$ The book begins to answer this fundamental question by making a distinction between "cause lawyering" and "political lawyering." 3 The authors frame cause lawyering to encompass a broad range of issues that differ based on their historical and cultural origins and geographic distribution. Cause lawyers, in other words, are activists and by definition they tend to operate on the margins of liberal societies to effect broad societal changes. The book instead focuses on political lawyering and its promotion and defence of political liberalism, as defined by the authors.

The authors' theory of political lawyering, focused on defending political liberalism, requires the basic building blocks of a liberal society. The conception of political liberalism employed by the authors is one that is related to the "restraint, distribution and control" of society's power. ${ }^{4}$ Providing a relatively narrow definition of political liberalism allows the authors to apply their theory to a broad range of cases. Political liberalism is defined narrowly in the book in terms of legal institutions. Acknowledging that the "concept of political liberalism is notoriously ambiguous and much contested," politically liberal society as one that guarantees basic freedoms and ensures a moderate state and civil society. The authors draw on both Alexis de Tocqueville and Jürgen Habermas in outlining the independence and discourse that informs civil society in a moderate, politically

Terence C. Halliday, Lucien Karpik \& Malcolm M. Feeley, eds., Fighting for Political Freedom: Comparative Studies of the Legal Complex and Political Liberalism (Oxford: Hart, 2007).

Terence C. Halliday, Lucien Karpik \& Malcolm M. Feeley, “The Legal Complex in Struggles for Political Liberalism” in ibid. 1 at 2 [Halliday, Karpik \& Feeley, “The Legal Complex”].

Ibid. at 3.

Ibid. at 12 .

Ibid. at 10, citing Eric Voegelin, "Liberalism and its History” (1974) 36 Review of Politics 504. 
liberal state. ${ }^{6}$ Interestingly, this type of society is not necessarily predisposed in favour of issues that are the domain of cause lawyers. Economic and social rights are not necessarily part of the politically liberal paradigm outlined in the book. There is some difficulty in drawing a precise line where basic freedoms end and causes begin. Although the book focuses on the struggle for basic freedoms, it could be argued that the logical extension of a struggle for basic freedoms would be acquisition of other rights, such as those based on T.H. Marshall's conception of civil, political, and economic rights based on citizenship.

Nevertheless, the authors are consistent, and in my view correct, in focusing on so-called first generation rights. The limits of political lawyering are essential to the universality of the authors' theories. Lawyers' privileged access to courts and legal information, as well as their relationship with the judiciary and their ability to effect change, differentiates them from other societal actors. The theme that emerges, however, is that political lawyers are more often reactive than proactive. Indeed, the authors make it very clear that the legal complex mobilizes in defending "negative," or first generation, individual rights against potential state oppression. Lucien Karpik writes that lawyers and the legal complex are fighting for basic freedoms - not necessarily for democracy — and this gives rise to one of the book's more contentious observations that democracy does not succeed to individual rights. ${ }^{7}$ Political lawyers thus react against the oppression of individual rights, rather than in favour of promoting social and economic rights. The many cases in the book clearly demonstrate that lawyers possess and have access to specific resources and knowledge that predispose them to this role in a variety of societies.

Although the theoretical chapters constitute the basis for the volume, the authors' theories are demonstrated by including 16 countries examined in the 16 case studies in the book. The authors frame the legal complex in the case studies as a set of relationships between legal actors, and these actors' orientation towards political liberalism and several models of action by the legal complex towards basic freedoms are illustrated in the case studies. They demonstrate conflicts between political liberalism and religion in proto-liberal societies where individuals find themselves in opposition over the same individual rights. This happens in the case of Turkey, where Zuhtu Arslan's essay illustrates that the legal complex has been mobilized largely in support of the state and the separation of the Turkish state and Islam. ${ }^{8}$

The most disturbing situation arises when the legal complex acts in almost complete opposition to basic freedoms. In the book's postscript, Karpik writes that in what members of the legal profession considered "extreme" cases, they acted more according to class logic than professional logic. ${ }^{9}$ The case of Chile, demonstrated in the book by Javier Couso's essay on the friendly attitude of the Chilean legal complex towards Augusto Pinochet's

Ibid. at 11, citing Alexis de Tocqueville, Democracy in America, trans. by George Lawrence (Garden City, N.Y.: Doubleday, 1969); Jürgen Habermas, The Structural Transformation of the Public Sphere: An Inquiry Into a Category of Bourgeois Society, trans. by Thomas Burger (Cambridge, Mass.: MIT Press, 1989).

$7 \quad$ Lucien Karpik, "Political Lawyers" in Halliday, Karpik \& Feeley, supra note 1, 463 at 469. Karpik makes the intuitive, yet still disturbing, observation that "[f]reedom and democracy do not go together easily: they belong to two different and contradictory worlds." 
dictatorship, supports this to a certain extent. ${ }^{10}$ In addition to overt opposition, the book also demonstrates that the silence of the legal complex in the face of politically illiberal acts can be a powerful signal to state authorities. Gad Barzilai's essay on the silence of the legal complex in Israel in the face of violations of basic individual rights ${ }^{11}$ and Daniel Brink's essay on the acquiescence of the legal complex to extrajudicial police violence in Argentina and Brazil in the 1970s and 1980s vividly illustrate the consequences when lawyers' silence replaces argument in defence of basic freedoms. ${ }^{12}$

One of the most complex and intriguing case studies in the book is penned by Robert Abel and deals with the partial support given by lawyers towards basic freedoms in the United States since 11 September $2001 .^{13}$ In his essay, Abel points to a divided judiciary and a docile mainstream media that refuses to challenge executive pronouncements in the name of national security. This essay is an important contribution in making the argument that there was a shift towards presidential primacy during the Bush administration. This atmosphere has served to marginalize and silence individual lawyers who tried to defend basic freedoms in an "exceptional" state of emergency that may in reality last a very long time. The executive, the corporate media, and elements of the legal complex combined to create a paradigm where many lawyers fought difficult battles to defend basic freedoms in the U.S. Yet these battles were fought, and often won, and this is the general point of this book. Lawyers continue to fight for basic freedoms even in the face of the most adverse circumstances. Abel's essay provides a very good demonstration of the author's theories in post-9/11 America.

Some of the essays in the book are somewhat less compelling in proving the authors' theories, but still provide important evidence to account for attitudes of the legal complex towards violations of basic freedoms. Total support of the legal complex towards basic freedoms is illustrated in the book by Rogelio Perez Perdomo's essay on the attitude of the Venezuelan legal complex towards political liberalism leading up to the current government of President Hugo Chavez. ${ }^{14}$ This is, as Karpik notes in the book's postscript, despite previous "symbiotic" relationships between the Venezuelan legal complex and various regimes, authoritarian and democratic. However, whatever their political orientation, these regimes helped perpetuate a huge class divide in oil-rich Venezuela. This brings to mind the issue of the legal complex and class logic versus professional logic explanations for the behaviour of lawyers. In simple terms, it is not clear whether the hostility of the legal complex towards the Chavez regime is a manifestation of class logic, or rather a continuation of historical trends in defence of political liberalism. Perhaps the most obvious solution in the Venezuelan context is that it is a bit of both. Similarly, the situation in Fascist Italy, referenced in the book in the Carlo Guarnieri's essay, demonstrates that a perceived anarchist and communist threat was a prime motivator in the support given by the Italian legal complex

Javier A. Couso, "When the 'Political Complex' Takes the Lead: The Configuration of a Moderate State in Chile” in Halliday, Karpik \& Feeley, supra note 1, 315.

Gad Barzilai, “The Ambivalent Language of Lawyers in Israel: Liberal Politics, Economic Liberalism, Silence and Dissent” in Halliday, Karpik \& Feeley, ibid., 247.

Daniel M. Brinks, “The Legal Complex and the Response to Police Violence in South America” in Halliday, Karpik \& Feeley, ibid., 281.

Richard L. Abel, “Contesting Legality in the United States after September 11” in Halliday, Karpik \& Feeley, ibid., 361.

Rogelio Perez Perdomo, “Lawyers and Political Liberalism in Venezuela” in Halliday, Karpik \& Feeley, ibid., 345 . 
for Benito Mussolini. ${ }^{15}$ As least in the early years of Fascist rule, the Italian legal complex acted according to class logic as members of a bourgeois middle class. This observation could, of course, be applied to the case of Chile under Pinochet, as well as the refusal to prosecute police in Brazil for extrajudicial killings.

However, these are mild criticisms. The book's premise is founded on the conceit that a politically liberal society forms the basis for a civil society that is not divided or fearful of state authorities. Class logic explanations cannot counter the voluminous proof of the book's general foundation, through the case studies, that globalization in its various forms has allowed politically liberal societies to expand, even in the face of historical absence or reversals. However, there is the possibility that political liberalism as an ideology can often act to mask vast social inequalities within society. In this context, globalization produces decidedly contradictory effects.

Karpik divides globalization and its effects on the legal complex into three neat categories — economic, ideological, and professional. ${ }^{16}$ The contradictions of globalization can be seen most readily in economic globalization, which, as noted in the book, has produced an everincreasing number of business and corporate lawyers working across national boundaries. The exporting of politically liberal values would seem to be neutralized by the overarching economic goals pursued by business and corporate interests. Thus, corporate lawyers may well be inclined towards political neutrality, or even antagonistic to basic freedoms, if those freedoms are seen to threaten corporate interests. In other words, democracy, freedom, and economic globalization may not easily coexist.

Ideological globalization, by contrast, has seen the global bar embrace a political liberalism after embracing economic liberalism during the 1970s and 1980s. Tom Ginsburg's essay on Korea and Taiwan provides a much needed glimpse into the transformation of the legal complex in northeast Asia and its embrace of political liberalism. ${ }^{17}$ The globalization of the legal profession - professional globalization - has taken up the cause of political liberalism. What emerges from the various case studies in the book is a dominant post-Cold War ideology that embraces basic freedoms, if not a universal conception of human rights. The authors note the intervention of the European Court of Human Rights in Turkey ${ }^{18}$ and the Council of Europe in Spain, ${ }^{19}$ although such intervention seems less effective outside of Europe. A minor limitation of the book is the failure to include any countries from Africa and South Asia in the case studies — Pakistan and Zimbabwe come readily to mind.

Finally, I would commend the authors for linking their theories so effectively to the case studies. The underlying question that the book asks, and goes a long way towards answering, pertains to the motivation of members of the legal complex to fight for basic freedoms. The authors note that political commitment by members of the legal complex offers only a partial explanation. It seems clear that the state and lawyers, perhaps unintentionally, often share

Carlo Guarnieri, "Lawyers and Statist Liberalism in Italy” in Halliday, Karpik \& Feeley, ibid., 439. Karpik, supra note 7 at 487.

Tom Ginsburg, "Law and the Liberal Transformation of the Northeast Asian Legal Complex in Korea and Taiwan” in Halliday, Karpik \& Feeley, supra note 1, 43.

Arslan, supra note 8 at 221.

Halliday, Karpik \& Feeley, "The Legal Complex,” supra note 2 at 18. 
a common perception of justice's benefit of civil peace. What emerges from the application of the authors' theories in the case studies is the notion that there is no single motivating factor beyond the belief that these individuals were simply doing their job in struggling for political liberalism. The book also raises some important issues regarding the role of political lawyers in countries with a long tradition of political liberalism, such as the U.S. By the end of the book, it becomes apparent that in this struggle lawyers are not helpless pawns but often crucial pieces in winning the fight for political liberalism.

Robert Russo

Ph.D. Student

Faculty of Law

University of British Columbia 